\title{
PENERAPAN MODEL KOOPERATIF TIPE THINK-PAIR-SHARE UNTUK MENINGKATKAN KECERDASAN LINGUISTIK SISWA SEKOLAH DASAR
}

\author{
Nining \\ SDN Cipaku 03 Kecamatan Paseh Kabupaten Bandung \\ Email: h.nining@gmail.com
}

Naskah diterima : 30 September 2018, direvisi : 5 Oktober2018, disetujui : 20 Oktober 2018

\begin{abstract}
Abstrct
This research is motivated by linguistic lowered sixth grade students of State Elementary School of Cipaku 03 in Bandung. The purpose of research is done is to determine the increase in linguistic six graders using cooperative model types think-pair-share. The method used is the method of action research (PTK), where PTK is an attempt by educators in order to improve teaching practices in the classroom, so PTK is very well executed by teachers to improve the quality of learning and minimize the problems that arise when learning practices. The instruments primarily used are observation sheets, linguistic intelligence test sheet, sheet interviews, teacher's notes and journals. Based on data obtained from tests of intelligence linguistics student, has obtained the discovery that the improvements concerning linguistic intelligence test results of students, so as to obtain results that the model of cooperative research think-pair-share to increase the intelligence linguistics students. Therefore, the authors recommend the type of cooperative model of think-pair-share to the teachers as one of the alternatives in an effort to improve the intelligence linguistics students in elementary school.
\end{abstract}

Keywords: Cooperative Model Type Think-Pair-Share, Linguistic Intelligence

Pengutipan: Nining. (2018). Penerapan Model Kooperatif Tipe Think-Pair-Share untuk Meningkatkan Kecerdasan Linguistik Siswa Sekolah Dasar. JMIE: Journal of Madrasah Ibtidaiyah Education, 2(2), 2018, 245-253. jmie.v2i2.76.

Permalink/DOI: http://dx.doi.org/ 10.32934/jmie.v2i2.76 


\section{PENDAHULUAN}

Pendidikan merupakan faktor paling penting dalam kemajuan suatu negara. Kualitas pendidikan sangat ditentukan oleh kualitas proses pembelajaran. Proses pembelajaran di kelas menjadi tumpuan diperolehnya lulusan yang tidak hanya mampu menguasai pengetahuan, namun juga diharapkan memiliki sikap dan keterampilan yang memadai. Untuk mencapai lulusan yang berkualitas dalam berbagai hal baik sikap, pengetahuan, maupun keterampilan maka disusunlah kurikulum pada setiap jenjang pendidikan yang terdiri dari beberapa mata pelajaran dan diharapkan dapat menunjang kompetensi lulusan.

Kecerdasan linguistik adalah kemampuan untuk menyusun pikiran dengan jelas dan mampu menggunakannya secara kompeten melalui kata-kata, seperti bicara, membaca dan menulis. Biasanya kecerdasan ini dimiliki oleh para orator, negoisator, pengacara, negarawan dan lain sebagainya (Lwin, dkk., 2003). Dengan segala kepiawaiannya, orang-orang yang mempunyai kecerdasan linguistik ini mampu mempengaruhi orang lain dengan mudahnya. Gaya bahasa, tutur kata, gerak verbal, mimik yang pas ketika bicara, semuanya mengandung daya pikat yang luar biasa.

Kecerdasan linguistik atau kecerdasan berbahasa ialah kemampuan seseorang untuk mengungkapkan pendapat atau fikirannya melalui bahasa verbal maupun non verbal. Amstrong (2013: 6) menyatakan bahwa "kecerdasan linguistik adalah kecerdasan yang meliputi kemampuan untuk menggunakan kata-kata dan bahasa secara efektif, bisa melalui pengucapan ataupun tulisan". Selain itu, kecerdasan ini juga meliputi kemampuan untuk memanipulasi langkah-langkah atau struktur bahasa, fonologi atau suara dari bahasa, sematik atau makna dari bahasa. Seseorang dengan kecerdasan linguistik yang kuat pada umumnya akan terampil dalam menggunakan kata-kata, menulis, mendengarkan, bercerita, membaca dan menghafalkan kata-kata. Sehingga individu ini akan belajar paling baik dengan membaca, menulis, membaca, mendengarkan penjelasan, berdiskusi serta berdebat tentang apa yang telah mereka pelajari.

Karakteristik dari kecerdasan linguistik adalah senang membaca semua betntuk bacaan, senang mencoret-coret atau menulis saat mendengarkan maupun berbicara, selalu memaparkan ide atau gagasannya dihadapan orang lain, senang bergabung pada acara-acara debat, diskusi, atau dialog dengan orang lain, sering menulis jurnal, dan seang pada pelajaran bahasa. Dalam kaitannya dengan psikologi, linguistik lazim diartikan sebagai ilmu yang mencoba mempelajari hakikat bahasa, stuktur bahasa, bagaimana bahasa itu diperoleh, bagaimana bahasa itu bekerja, dan bagaimana bahasa itu 
berkembang. Dalam konsep ini terlihat bahwa yang namanya psikolinguistik dianggap sebagai cabang dari linguistik, sedangkan linguistik itu sendiri dianggap sebagai cabang dari psikologi.

Ada beberapa masalah mengenai kecerdasan linguistik tepatnya pada keterampilan berbicara pada siswa, diantaranya: siswa tidak berani mengemukakan pendapat atau tidak pernah bertanya apabila ada materi yang tidak jelas menurut siswa. Kemudian, siswa juga masih malu untuk berbicara didepan kelas apabila diperintah guru untuk membacakan sebuah pengumuman. Penyebab dari masalah diatas salahsatu nya ialah, karena siswa kurang memahami materi yang disampaikan guru, kemudian siswa juga belum terbiasa maju kedepan. Akibat atau dampak yang akan terjadi apabila siswa dibiarkan ialah siswa tidak akan pernah berani mengungkapkan apa yang mereka tidak ketahui dan ketahui, ini juga akan berdampak negatif bagi kedepannya. Selain itu, masalah rendahnya kecerdasan linguistik siswa akan berpengaruh terhadap prestasi siswa pada pembelajaran Bahasa Indonesia. Hal ini dibuktikan dari hasil penelitian Umarean, dkk (2014) yaitu: (1) terdapat hubungan yang signifikan antara kecerdasan linguistik terhadap prestasi belajar bahasa Indonesia sebesar 33,52\%. (2) terdapat hubungan yang signifikan antara konsep diri terhadap prestasi belajar bahasa Indonesia sebesar 23,61\% (3) terdapat hubungan yang signifikan secara bersama-sama antara kecerdasan linguistik dan konsep diri dengan prestasi belajar bahasa Indonesia sebesar $37,21 \%$.

Oleh karena itu, masalah rendahnya kecerdasan linguistik siswa harus segera diatasi. Salah satu penyelesaian nya bisa dengan menggunakan model kooperatif tipe think-pair-share. Jadi selama pembelajaran berlangsung seorang guru bias membagi siswa menjadi beberapa kelompok untuk berbagi pengetahuan sesama anggotanya dalam pembelajaran Bahasa Indonesia supaya siswa dapat dengan aktif mengungkapkan apa yang mereka ingin tanyakan atau tidak malu apabila disuruh untuk maju kedepan.

Model Pembelajaran Kooperatif tipe TPS atau (Berfikir-Berpasangan-Berbagi) adalah jenis pembelajaran yang dibuat untuk mempengaruhi interaksi antar siswa. Think Pair Share menghendaki siswa bekerja sama saling membantu dalam sebuah kelompok kecil yang terdiri dari 2-6 orang (Ibrahim dkk: 2000: 3). Penggunaan model pembelajaran Kooperatif tipe TPS bertujuan agar siswa dapat mengembangkan daya berfikir dan menjawab konsep yang dikomunikasi antara satu dengan yang lain, serta bekerja saling membantu antar anggota kelompok. Seperti yang dijelaskan Lie (2004) Think-Pair-Share adalah pembelajaran yang memberi ruang kepada siswa untuk bekerja dengan kemampuannya sendiri dan bekerja dengan kelompok. 
Think pair share adalah suatu tipe pembelajaran atau teknik sederhana dengan keuntungan yang sangat besar (Hamdayana, 2014 : 201). TPS dapat mempengaruhi kemampuan siswa dalam mengingat informasi yang dipelajari dan menyampaikan pemikirannya untuk didiskusikan sebelum disampaikan didepan kelas. Dengan begitu jelas bahwa model pembelajaran Think-Pair-Share bisa secara langsung untuk membantu siswa dalam memecahkan kasus, memahami suatu konsep materi secara berkelompok dan saling membantu dengan yang lainnya, lalu membuat kesimpulan berdasarkan hasil diskusi serta mempresentasikan hasil diskusi di depan kelas sebagai salah satu langkah evaluasi pembelajaran yang telah dilakukan.

Model pembelajaran kooperatif tipe think pair share diawali dengan siswa berpikir (thinking) masalah yang telah diberikan oleh guru, selanjutnya siswa diminta untuk berpasangan (pairing) untuk mendiskusikan jawaban, selanjutnya yaitu berbagi (share) jawaban yang telah di diskusikan bersama kelompok. Dalam pembelajaran model kooperatif tipe think pair share, siswa diberi kesempatan untuk berbagi pengetahuan kepada teman kelompoknya, sehingga mereka dituntut untuk mengeluarkan pendapat, dan mampu berkomunikasi secara lisan dengan baik. Oleh karena itu, model kooperatif tipe think pair share dianggap dapat meningkatkan kecerdasan linguistik siswa sekolah dasar.

\section{METODE PENELITIAN}

Penelitian dilaksanakan pada siswa kelas VI SDN Cipaku 03 Kecamatan Paseh Kabupaten Bandung Tahun Ajaran 2017-2018 dengan menggunakan metode Penelitian Tindakan Kelas (PTK), dimana Hopkins (Muslich, 2009: 8) menjelaskan bahwa PTK merupakan suatu bentuk kajian yang bersifat reflektif, yang dilakukan oleh pelaku pendidikan untuk meningkatkan kemantapan rasional dari tindakan-tindakannya dalam melaksanakan tugas dan memperdalam pemahaman terhadap kondisi dalam praktik pembelajaran. Desain Penelitian Tindakan Kelas (PTK) yang digunakan dalam penelitian ini adalah model yang diungkapkan oleh Kemmis dan Mc Taggart. Dimana Kemmis dan Mc. Taggart (Wiriaatmadja, 2008: 66) mengungkapkan bahwa dalam PTK ada empat tahapan penting yang harus dilaksanakan, Keempat tahapan penting tersebut juga merupakan tahap-tahap penelitian yang akan dilaksanakan pada penelitian kali ini, tahap-tahap tersebut yaitu (1) perencanaan (plan), (2) aksi/tindakan (act), (3) observasi (observe), dan (4) refleksi (reflect). 


\section{HASIL PENELITIAN}

Pada pelaksanaan tindakan pembelajaran menggunakan model kooperatif tipe think-pair-share. Pada awal kegiatan pembelajaran guru selalu memulai dengan mengucapkan salam dan berdoa bersama. Setelah itu dilanjutkan dengan memeriksa kehadiran dan kesiapan siswa untuk belajar. Kemudian guru menyampaikan tujuan pembelajaran. Selanjutnya, guru melakukan apersepsi dengan selalu mengaitkan materi pembelajaran dengan kehidupan nyata siswa. Pembelajaran inti dimulai dengan memberikan siswa salah satu contoh cerita rakyat.

Kemudian, guru memberikan suatu permasalahan yang berhubungan dengan topik cerita rakyat, kemudian siswa diminta untuk memikirkan pertanyaan tersebut untuk beberapa saat. Dalam tahap ini siswa dituntut untuk lebih mandiri dalam mengolah informasi yang dia dapat. Pada saat ini, siswa Nampak memperdsalamnya dengan tanya jawab secara individu maupun klasikal. Siswa sudah Saat pembelajaran berlangsung, guru memberikan tugas secara berkelompok. Siswa dapat menyelesaikan tugas tersebut dengan berdiskusi. Pada saat ini, siswa nampak antusias dalam melaksanakan diskusi, mereka mampu pengeluarkan pendapat mengenai cerita rakyat yang dibahas. Kemudian guru meminta kepada setiap kelompok untuk membagikan atau mempresentasikan jawaban yang telah didiskusikan di depan kelas. Seletah itu, pembelajaran ditutup dengan menarik kesimpulan bersama-sama. Tak lupa memberikan siswa diberi kesempatan untuk bertanya terkait materi yang belum dipahami. Guru menutup dengan berdoa bersama dan mengucapkan salam.

Selain itu, peneliti dibantu oleh observer untuk mengobservasi aktivitas guru dan aktivitas siswa selama proses kegiatan belajar mengajar berlangsung. Observer mengobservasi aktivitas guru dan siswa, hasil observesi menunjukkan keberhasilan terhadap penerapan pembelajaran koopertaif tipe think-pair-share yang telah dilaksanakan pada kegiatan pembelajaran siklus I, II, dan III. Berdasarkan data aktivitas guru diperoleh nilai 69 pada siklus I dengan kategori cukup, kemudian pada siklus II diperoleh nilai 78 dengan kategori baik, dan mendapatkan nilai 85 pada siklus III dengan kategori sangat baik. Sedangkan untuk data aktivitas siswa diperoleh nilai 68 pada siklus I dengan kategori cukup, kemudian pada siklus II diperoleh nilai 76 dengan kategori baik, dan mendapatkan nilai 83 pada siklus III dengan kategori sangat baik. Adapun peningkatan hasil observasi aktivitas guru dan siswa dari siklus I, siklus II, dan siklus III juga dapat disajikan dalam diagram di bawah ini: 


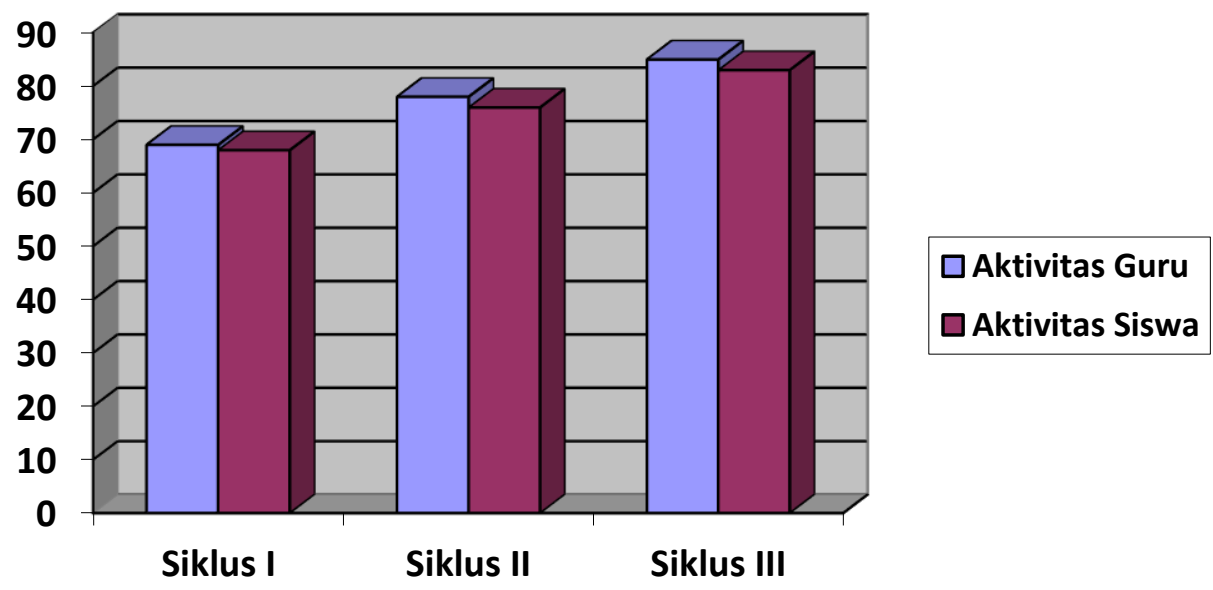

Diagram 1

\section{Hasil Observasi Aktivitas Guru dan Siswa}

Penilaian dilakukan setelah tiga kali pertemuan. Indikator ketercapaian kecerdasan siswa pada penelitian ini yaitu apabila hasil persentase kecerdasan siswa lebih dari 75\% dengan kriteria nilai minimal 75 pada setiap tes. Peningkatan rata-rata hasil dari tes kecerdasan linguistik siswa dari siklus I, siklus II, dan siklus III terdapat pada tabel berikut:

Tabel 1. Nilai Rata-Rata Kecerdasan Linguistik Siswa

\begin{tabular}{lc}
\hline \multicolumn{1}{c}{ Pelaksanaan } & Nilai Rata-Rata \\
\hline Siklus I & 67 \\
Siklus II & 75 \\
Siklus III & 88 \\
\hline
\end{tabular}

Peningkatan rata-rata nilai kecerdasan linguistik siswa dari siklus I, siklus II, dan siklus III juga dapat disajikan dalam diagram di bawah ini: 


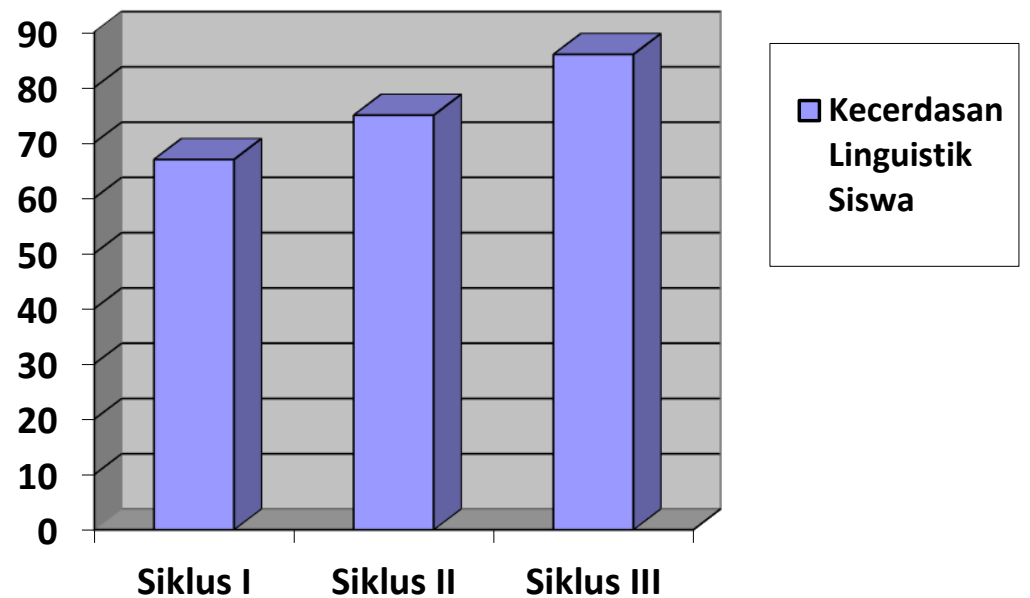

\section{Diagram 2. Peningkatan Nilai Rata-Rata Kecerdasan Linguistik Siswa}

Berdasarkan diagram di atas, dapat diketahui terdapat peningkatan kecerdasan linguistik siswa kelas IV SDN Cipaku 03 Kecamatan Paseh Kabupaten Bandung yang menggunakan model kooperatif tipe think-pair-share pada setiap siklusnya. Dari siklus I ke siklus II mengalami peningkatan sebesar 8, dan dari siklus II ke siklus III mengalami peningkatan sebesar 13 .

Hasil penelitian menunjukkan bahwa model kooperatif tipe think pair share dapat meningkatkan kecerdasan linguistik siswa. Hal tersebut senada dengan hasil penelitian Fatiman (2015) yang menunjukkan implementasi model kooperatif tipe think pair share dapat meningkatkan keterampilan bercerita siswa dengan langkah-langkah: (1) tahapan pembelajaran bercerita dengan metode model kooperatif tipe think pair share dalam rencana pembelajaran yang dibuat guru secara spesifik sesuai dengan tahapan umum metode tersebut secara teoretis, (2) implementasi metode model kooperatif tipe think pair share selama proses pembelajaran bercerita sesuai dengan tahapan skenario pembelajaran yang telah dikemukakan dalam rencana proses pembelajaran yang dibuat oleh guru, (3) apresiasi terhadap implementasi model kooperatif tipe think pair share baik dari pengguna metode yaitu guru maupun siswa sebagai penerima metode cukup baik.

Selain hasil penelitian yang membuktikan bahwa model kooperatif tipe think pair share dapat meningkatkan keterampilan bercerita siswa. Hasil penelitian lain yang dilakukan Damayanti, dkk (2016) menunjukkan bahwa model kooperatif tipe think pair share dapat meningkatkan kemampuan menyimak siswa dalam pembelajaran Bahasa Indonesia. Keterampilan berbicara dan menyimak merupakan keterampilan dalam 
pembelajaran Bahasa Indonesia, sehingga hal tersebut senada dengan hasil penelitian ini, bahwa model kooperatif tipe think pair share dapat meningkatkan kecerdasan linguistik siswa sekolah dasar.

\section{KESIMPULAN}

Peneliti melakukan proses pembelajaran yang menggunakan model kooperatif tipe think-pair-share pada pembelajaran Bahasa Indonesia di kelas IV SDN Cipaku 03 Kecamatan Paseh Kabupaten Bandung Tahun Ajaran 2017-2018. Pada awal kegiatan pembelajaran dimulai dengan mengucapkan salam dan berdoa bersama dilanjutkan dengan memeriksa kehadiran dan kesiapan siswa untuk belajar. Kemudian melakukan apersepsi yang mengaitkan materi dengan kehidupan nyata siswa. Setelah melakukan apersepsi, guru memberi kesempatan kepada siswa untuk menganalisis suatu cerita rakyat secara kelompok. Siswa diberi kesempatan untuk mengajukan pertanyaan mengenai cerita tersebut. Kemudian siswa diberi waktu untuk berdiskusi secara kelompok menegnai cerita yang dibahas. Setelah itu, siswa diberi kesempatan untuk mempresentasikan hasil diskusi kelompoknya di depan kelas. Sampai akhirnya, pembelajaran ditutup dengan menarik kesimpulan bersama-sama, memberikan siswa kesempatan untuk bertanya terkait materi yang belum dipahami, berdoa bersama dan mengucapkan salam.

Hasil observasi aktivitas guru diperoleh nilai 69 pada siklus I dengan kategori cukup, kemudian pada siklus II diperoleh nilai 78 dengan kategori baik, dan mendapatkan nilai 85 pada siklus III dengan kategori sangat baik. Sedangkan untuk data aktivitas siswa diperoleh nilai 68 pada siklus I dengan kategori cukup, kemudian pada siklus II diperoleh nilai 76 dengan kategori baik, dan mendapatkan nilai 83 pada siklus III dengan kategori sangat baik. Kemudian, hasil kecerdasan linguistik siswa siklus I mencapai 67 dengan kategori cukup, hasil kecerdasan linguistik siswa siklus II mencapai 75 dengan kategori baik, sedangkan hasil kecerdasan linguistik siswa siklus III mencapai 88 dengan kategori sangat baik. Selain itu, dari siklus I ke siklus II mengalami peningkatan sebesar 8, serta dari siklus II ke siklus III mengalami peningkatan sebesar 13. 


\section{DAFTAR PUSTAKA}

Armstrong, Thomas, (2013). Kecerdasan Multiple di Dalam Kelas. Jakarta: PT Indeks. Damayanti, dkk (2016). Model Pembelajaran kooperatif Tipe Think Pair Share Untuk Meningkatkan Keterampilan Menyimak Mata Pelajaran Bahasa Indonesia di SLB B Nengeri Cicendo Bandung.JASSI_Anak.ku. 7. (1). 8-13.

Fatimah, N. (2015). Implementasi Cooperative Learning Tipe Think-Pair-Share dalam Pembelajaran Bercerita di Sekolah Menengah Pertama. Jurnal Penelitian Humaniora. 16. (2). 90-98.

Hamdayana, Jumata. (2014). Model dan Metode Pembelajaran Kreatif dan Berkarakter. Ghalia Indonesia. Jakarta.

Ibrahim., M.R.Fida., M.Nur dan Ismono. (2000). Pembelajaran Kooperatif. Surabaya. Universitas Negeri Surabaya.

Lie, Anita. (2004). Cooperative Learning. Jakarta: Gramedia Widiasarana Indonesia.

Lwin, M. (2008). How to Multiply Your Child Intelligence-Cara Mengembankan Berbagai Komponen Kecerdasan. Indek: Yogyakarta

Muslich, M. (2009). Melaksanakan PTK Itu Mudah. Jakarta: PT Bumi Aksara.

Umareani, N.P.D., Putra, I.K.A., dan Asri, I.G.A.A.S. Hubungan Antara Kecerdasan Linguistik dan Konsep Diri Dengan Prestasi Belajar Bahasa Indonesia Siswa Kelas V Gugus Kompyang Sujana. Jurnal Mimbar PGSD Universitas Pendidikan Ganesha. 2. (1). 1-10.

Wiriaatmadja. R. (2008). Metode Penelitian Tindakan Kelas. Bandung: PT Remaja Rosdakarya. 